\title{
Herring Investigations at Plymouth. VII. On the Artificial Fertilisation and Hatching of Herring Eggs under known Conditions of Salinity, with some Observations on the Specific Gravity of the Larvæ.
}

\author{
By \\ E. Ford, A.R.C.Sc., \\ Naturalist at the Plymouth Laboratory.
}

\section{INTRODUCTION.}

IT has previously been shown (Ford, 1, p. 284) that herrings with fully ripened roes or milts form a considerable proportion of the landings by commercial drifters at Plymouth during December and January. Although naturally-deposited spawn has rarely been obtained from the sea-bottom in the district, the fact that newly-hatched larvæ occur in abundance provides evidence that actual spawning occurs locally. It has also been shown that from the end of September onwards, ripe fishes may be taken in stop-nets in Plymouth Sound, and even in sprat-seines in the estuarine waters of the River Tamar. A number of interesting and important questions is suggested by these observations. For example, do the ripe herrings which frequent the River Tamar actually spawn there, and if so, are they morphologically identical with those which spawn at sea, or are they of a different character? Would eggs deposited in the river be successfully fertilised and able to endure the periodic freshening of the water? Are the morphological characters of the offispring in any way dependent upon the environmental conditions under which they are developed?

It is a comparatively simple process to express the eggs from a recentlydead ripe female on to glass plates, and then to fertilise them with the milt from a ripe male. The fertilised eggs develop quite normally in sea-water and give a good yield of apparently healthy and active larvæ. Unfortunately, however, it seems impossible at present to rear these larvæ beyond the stage at which the yolk-sac is absorbed. Thus, while we can readily obtain a batch of larvæ from the artificial crossing of parents of known character, we cannot, as yet, rear the young to the stage at which they exhibit the adult characters used to define the parents. It will be realised that this fact is a serious hindrance to progress along 
the lines of investigation under consideration, and it is to be hoped that some worker will soon be able to devote time to discover how successfully to rear herring larvæ. The problem will need undivided attention; it is not one likely to be solved as an incidental to other investigations.

There are, however, important initial points which can be cleared up by experiments in artificial fertilisations alone. During the winter of 1928-29 some preliminary tests were made, having as their object the determination of the effects of changing salinity as one leading environmental factor. The nature of the experiments and the results obtained are discussed below.

\section{Experiment A.}

During the evening of January 14th, 1929, eggs from a ripe female herring $27.5 \mathrm{~cm}$. in length were expressed on to four glass plates and fertilised by the milt of a ripe male $27.3 \mathrm{~cm}$. in length. Laboratory tankroom sea-water was used throughout the fertilisations, at a temperature of $7 \cdot 5^{\circ} \mathrm{C}$. On the morning of January 15 th the plates with the developing eggs were transferred, one to each of the following tanks :-

Tank 1. 8000 cc. Laboratory tank-room sea-water.

Tank 2. $4000 \mathrm{cc}$.

Tank 3.2000 cc.

Tank 4. $1000 \mathrm{cc}$.

$\begin{array}{lll}, \quad+4000 \mathrm{cc} . & \text { fresh-water from tap. } \\ , & +6000 \mathrm{cc} . \quad, & , \\ , & +7000 \mathrm{cc} . \quad, & ,\end{array}$

The salinities of these tanks, determined by titration against silver nitrate solution according to the method recommended by Harvey (2, p. 37), were as follows :-

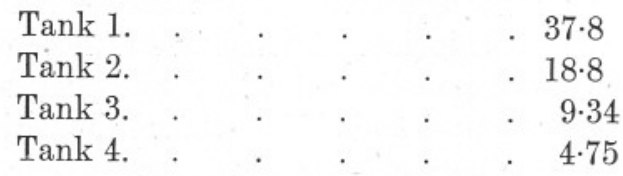

Rough sketches of the disposition of the eggs on each plate were made, indicating unfertilised eggs. These sketches provided a means of ascertaining at a glance if any eggs died subsequent to transference to the test tanks. Each tank was aerated continuously throughout the experiment. On January 25th, larvæ began to hatch out in Tanks 1 and 2, and, on the following day, in the remaining Tanks 3 and 4 . No eggs had apparently died during the experiment. Within the next two or three days the whole of the eggs in Tanks 1 and 2 hatched out, but in Tanks 3 and 4, particularly the latter, many of the larvæ appeared rather weakly, for although they broke through the egg-envelope, they were unable to wriggle entirely free from it. On February 4 th, ten days after the first larvæ were hatched, a few individuals still remained alive in all four tanks. 
There was, however, a greater percentage of survivors in Tanks 1 and 2 than in Tanks 3 and 4.

Thus, eggs fertilised in tank-room sea-water will survive exposure to freshened sea-water of a salinity at least as low as 5, and give rise to living larvæ, some of which will remain alive in that water until the absorption of the yolk has reached an advanced stage.

\section{EXPERIMENT B.}

On January 22nd an attempt was made to obtain successful fertilisations, not only in sea-water of normal salinity, but in different mixtures of salt and freshwater. A female of $28.5 \mathrm{~cm}$. and a male of $28.3 \mathrm{~cm}$. were used for the experiment and operations conducted in water of from $9^{\circ}-10^{\circ} \mathrm{C}$. The following were the results :-

\begin{tabular}{|c|c|c|c|c|}
\hline \multicolumn{4}{|c|}{ Water used. } & \multirow[b]{2}{*}{ Result. } \\
\hline Plate No. & Sea-water. & Fresh (ta & Salinity. & \\
\hline 1 & 2000 cc. & - & $37 \cdot 8$ & Successful fertilisation. \\
\hline 2 & $1000 \mathrm{cc}$. & 1000 & $19 \cdot 0$ & ", \\
\hline 3 & $250 \mathrm{cc}$. & 1750 & $4 \cdot 8$ & ," \\
\hline 4 & $125 \mathrm{cc}$. & 1875 & $2 \cdot 4$ & $\begin{array}{l}\text { One or two eggs fertilised, } \\
\text { remainder unfertilised. }\end{array}$ \\
\hline 5 & - & 2000 & 一 & Failure. \\
\hline
\end{tabular}

Thus, actual fertilisation seems certainly possible in water of salinity of $4 \cdot 8$, and may even be possible in still fresher water down to a salinity of $2 \cdot 5$.

Plates 1, 2, and 3 carrying the successfully fertilised eggs were placed in tanks of water of the following salinities :-

\begin{tabular}{cccc} 
& \multicolumn{2}{c}{ Tank. } & \\
Plate No. & Sea-water. & Fresh (tap) & Salinity. \\
1 & $2000 \mathrm{cc}$. & - & $37 \cdot 8$ \\
2 & $1000 \mathrm{cc}$. & 1000 & $19 \cdot 0$ \\
3 & $250 \mathrm{cc}$. & 1750 & $4 \cdot 8$
\end{tabular}

On February 4th larvæ hatched from the eggs on all three plates. That is to say, eggs fertilised in water of salinity as low as 5 will develop in that water and give rise to living larvæ.

Now although the results of these experiments need confirmation - and elaboration, they are of immediate local application. If the eggs of herrings taken from the sea are capable not only of being fertilised, but also of undergoing successful incubation in water varying in salinity from $37 \cdot 8$ to $4 \cdot 8$, it is perfectly logical to believe that, so far as salinity is concerned, the fishes experimented with could, if they had been free to choose, have spawned on any suitable ground either outside or 
within Plymouth Sound or at places some considerable distance up the rivers Tamar and Lynher, with fair chances of a satisfactory brood of larvæ.

\section{Specific Gravity of Larvæ.}

Herring larvæ in an aquarium filled with ordinary sea-water, when not actually swimming, tend to sink at an appreciable rate. During the course of experiments $\mathrm{A}$ and $\mathrm{B}$ above, the impression was gained that larvæ in diluted sea-water sank more quickly than those in undiluted, and, in consequence, were more often at the bottom of the aquaria than at the surface. It was therefore decided to make some comparisons between larvæ incubated and reared in different strengths of sea-water, regarding their specific gravity. The method was to determine by trial and error the particular one of a series of brines of known strength in which a larva would remain in equilibrium, neither rising nor falling.

The standard brine used was 100 grammes of common salt dissolved in $500 \mathrm{cc}$. of tap-water, and the following series of test brines was made up at a temperature of $12^{\circ} \mathrm{C}$. :-

\begin{tabular}{|c|c|c|c|c|c|c|}
\hline $\begin{array}{l}\text { Test } \\
\text { Brine }\end{array}$ & $\begin{array}{c}\text { Standard } \\
\text { Brine }\end{array}$ & $\begin{array}{l}\text { Tap- } \\
\text { water }\end{array}$ & \multirow{3}{*}{\multicolumn{4}{|c|}{$\begin{array}{l}\text { Actual Strength of Test Brine } \\
10 \mathrm{grm} . \mathrm{NaCl} \text { per } 100 \mathrm{cc} \text {. }\end{array}$}} \\
\hline & & & & & & \\
\hline 1 & 50 & 50 & & & & \\
\hline 2 & $47 \cdot 5$ & $52 \cdot 5$ & $9 \cdot 5$ & ,, &, & \\
\hline 3 & 45 & 55 & $9 \cdot 0$ & ," & , & $"$ \\
\hline 4 & 42.5 & 57.5 & $8 \cdot 5$ & ", & ", & , \\
\hline 5 & 40 & 60 & $8 \cdot 0$ & ," & ", & ", \\
\hline 6 & 37.5 & 62.5 & $7 \cdot 5$ & ", & ", & ", \\
\hline 7 & 35 & 65 & $7 \cdot 0$ & , & , & ," \\
\hline 8 & 32.5 & $67 \cdot 5$ & 6.5 & $"$ & , & , \\
\hline 9 & 30 & 70 & $6 \cdot 0$ & ", & , & ," \\
\hline 10 & 27.5 & 72.5 & $5 \cdot 5$ & ", & ," & , \\
\hline 11 & 25 & 75 & $5 \cdot 0$ & ", & , & , \\
\hline 12 & 22.5 & 77.5 & $4 \cdot 5$ & ," & ," & ," \\
\hline 13 & 20 & 80 & $4 \cdot 0$ & ", & ," & ," \\
\hline 14 & $17 \cdot 5$ & 82.5 & 3.5 & , & ,, & ,, \\
\hline
\end{tabular}

The number of larvæ available for experiment was limited, and no opportunity presented itself later to make further fertilisations, so that the results obtained are tentative. Some difficulty, also, was experienced in actual practice, on account of the intermittent swimming of the larvæ in the test brines; in future tests it might be profitable to employ an anæsthetic.

It soon became evident that the specific gravity of the larva depended upon the amount of unabsorbed yolk in the yolk-sac, newly-hatched 
larvæ remaining in equilibrium in much stronger brine than larvæ some 10 days old. In the following table the results are given for tests of larvæ of different ages. The larvæ used were all hatched from eggs fertilised and incubated in sea-water of salinity $37 \cdot 8$ :-

No. of larvæ remaining in equilibrium in following test brines :-

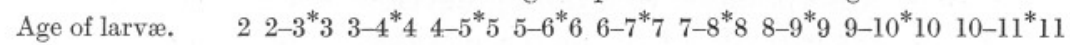

6 hours or less

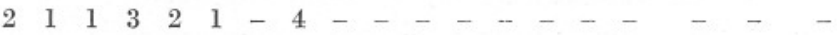
after hatching

24 hours or less

2nd day after hatching

3rd day after hatching

4th day after hatching

9-10 days after hatching

10-12 days after

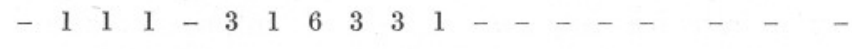

In consequence of this difference of specific gravity due to the quantity of unabsorbed yolk, it will be appreciated that, in attempting to draw comparisons between larvæ fertilised and/or incubated in different strengths of sea-water, it is essential that the larvæ compared should be of similar age and of the same parentage. In the present series, such material was limited, but the results tabulated below are interesting and suggestive although they need confirmation :-

Age of larvæ.

Maximum of

$24 \mathrm{hrs}$. after hatching

\section{Larve from Experiment B (above).}

Larvæ hatched from
eggs fertilised and
incubated in water of
following salinity.
$37 \cdot 8$
19.0
4.8

No. larvæ remaining in equilibrium in following test brines.

$\begin{array}{lllllllllllllllll}2 & 2-3 & 3 & 3-4 & 4 & 4 & -5 & 5 & 5 & -6 & 6 & 6-7 & 7 & 7-8 & 8 & 8-9 & 9\end{array}$

$12-21--2-\ldots-\ldots$

$-1-1-\ldots \overline{1} \overline{1} \overline{1}-\overline{3}-\overline{1}-$

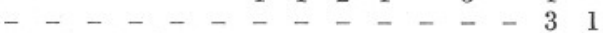

\section{Larva From Experiment A (ABOve).}

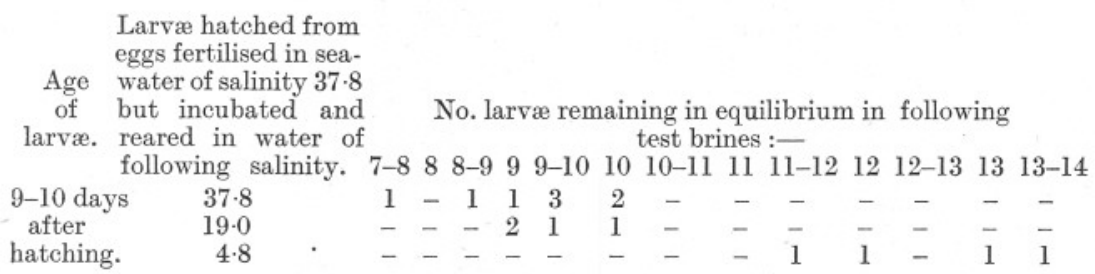

* The interval classes 2-3, 3-4, etc., indicate that the larvæ concerned do not remain in equilibrium in any one of the series of brines. Thus, a larvæ entered in Class 2-3 rises in brine 2 and falls in brine 3 . 
These results suggest that by incubating eggs in freshened water and allowing the newly-hatched larvæ to develop under the same salinity conditions, the specific gravity becomes reduced at a rate dependent upon the degree of freshening of the water.

The phenomenon of changing specific gravity of larvæ, due either to the gradual absorption of yolk during development or to the fact that incubation was carried out in freshened water, or both, would seem to merit attention. Herring larvæ being appreciably heavier than the water in which they live will tend to sink to the sea-bottom unless they persistently swim towards the surface; upward progress will be less easy for newly-hatched larvæ than for older ones on account of their higher specific gravity and their inferior swimming power. Questions relating to horizontal and vertical distribution of herring larvæ at different ages may well be affected by such factors.

In the second place, the differences of specific gravity induced by freshening of the water may conceivably have its effect on the metabolism of the larva, with a resulting morphological reaction. Such would be a highly important matter in all questions relating to racial investigations.

The results of these preliminary experiments, therefore, suggest that a fuller investigation along the lines indicated would be most profitable.

\section{LITERATURE CITED.}

1. Ford, E. " Herring Investigations at Plymouth. III. The Plymouth Winter Fishery during the Seasons 1924-25, 1925-26, and 1926-27." Journ. Mar. Biol. Assoc., Vol. XV, No. 1, February, 1928.

2. Harvey, H. W. "Biological Chemistry and Physics of Sea-water." Cambridge, 1927. 